\title{
PARADIGM OF CULTURAL RESEARCH: ADDRESS TO THE 75TH ANNIVERSARY OF MYKOLA ZYMOMRYA
}

\author{
ПАРАДИГМА КУЛЬТУРОЛОГІЧНИХ ДОСЛІДЖЕНЬ: \\ СЛОВО ДО 75-РІЧЧЯ МИКОЛИ ЗИМОМРІ
}

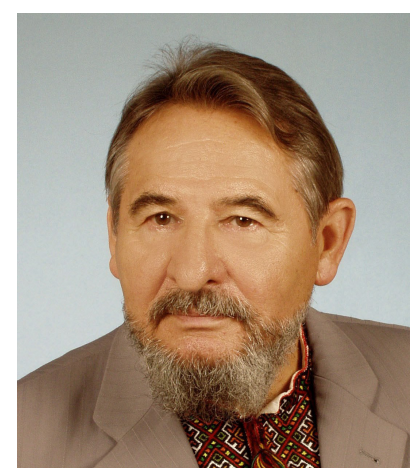

\author{
Zymomrya I.M. \\ orcid.org/0000-0003-3211-8268 \\ Doctor of Philological Sciences, Professor, \\ Head of Department of the Theory and Practice of Translation, \\ Faculty of International Economic Relations \\ Uzhhorod National University
}

Zhovtani R.Y. orcid.org/0000-0002-7421-148X Candidate of Philological Sciences, Associate Professor, Head of Department of International Communication, Faculty of Tourism and International Communication Uzhhorod National University

\author{
Zymomrya O.M., \\ orcid.org/0000-0001-7206-0190 \\ Candidate of Philological Sciences, \\ Associate Professor at the Department of International Communication, \\ Faculty of Tourism and International Communication \\ Uzhhorod National University
}

The article is dedicated to the 75th anniversary of the birth of a well-known literary critic, translator, educationalist, Doctor hab. of Philological Sciences, Professor Mykola Zymomrya. The article reflects the main milestones of his life and career. Mykola Zymomrya was born in 1946 in Holatyn in Ukraine. Main directions of activity: German studies, Slavic studies, contrastive literary studies, theory of literature, translation studies. Professional career: finished secondary school in Holatyn and graduated from Uzhhorod State University (Departments of Ukrainian and German Philology). After graduating from the Faculty of Foreign Languages (1967) was a teacher of the German language and literature at the Department of German Philology; a doctorate (1969-1972) at Humboldt University of Berlin where his doctoral thesis was written on the topic "Perception of Ukrainian literature in German-speaking countries from its origins to 1917. To the history of Ukrainian-Russian-German literary relations" (1972). His doctoral dissertation on the topic "Interliterary Relations and the Role of Translation in the Art Process" was written in the Gorky Institute of World Literature of the Russian Academy of Sciences in Moscow and was defended in 1984. Academic titles: assistant professor (1976); professor (1987). Head of the Department of German Philology (1974-1979); scientific worker at the Gorky Institute of World Literature (1980-1982); head of the Department of Foreign Languages at Uzhhorod State University (1986-1993); pro fessor at Higher Pedagogical School in Słupsk (1993-1995); professor at Transcarpathian Institute of Postgraduate Pedagogical Education (1996-2002); professor at Baltic High School of Human Sciences in Koszalin (1997-2002); professor at Polonia University in Czestochowa (2002-2012); professor at Drohobych State Pedagogical University of Ivan Franko (since 2000), head of the Department of Theory and Practice of Translation (2003-2010), head of Germanic Languages and Translation Studies Department (since 2010). Over 1000 scientific articles have been published (1970-2021) on issues in literature studies and criticism in newspapers, periodical publications, thematic collections, monographic publications.

Key words: scientific works of Mykola Zymomrya, literary studies, theory of literature, translation studies, perception, Interliterary relations. 
Стаття присвячена 75-річному ювілею відомого літературознавця, перекладача, педагога, доктора філологічних наук, проф. Миколи Зимомрі. У статті відображені основні віхи життя та творчості науковця. Микола Зимомря народився 1946 року в с. Голятин. Основні напрями діяльності: германістика, славістика, порівняльне літературознавство, теорія літератури, перекладознавство. Професійна діяльність: закінчив середню школу в Голятині та Ужгородський державний університет (кафедри української та німецької фрілології). Після закінчення фракультету іноземних мов (1967) був викладачем німецької мови та літератури на кафедрі німецької фрілології; в 1969-1972 рр. був аспірантом Берлінського університету імені Гумбольдта, де була написана його докторська дисертація на тему «Сприйняття української літератури в німецькомовних країнах від першовитоків до 1917 року. До історії українсько-російсько-німецьких літературних зв'язків» (1972). Його докторська дисертація на тему «Міжлітературні зв'язки та роль перекладу в художньому процесі» написана в Інституті світової літератури імені Горького РАН у Москві й захищена в 1984 р. Вчені звання: доцент (1976); професор (1987). Завідувач кафедри німецької фрілології (1974-1979); науковий співробітник Інституту світової літератури імені Горького (1980-1982); завідувач кафедри іноземних мов УжДУ (1986-1993); професор Вищої педагогічної школи в Слупську (1993-1995); професор Закарпатського інституту післядипломної педагогічної освіти (1996-2002); профессор Балтійської вищої гуманістичної школи у Кошаліні (1997-2002); професор Полонійної академії в Ченстохові (2002-2012); професор Дрогобицького державного педагогічного університету імені Івана Франка (з 2000), завідувач кафредри теорії та практики перекладу (2003-2010), завідувач кафедри германських мов та перекладознавства (з 2010). Опублікував понад 1000 наукових статей (1970-2021) з питань літературознавства та критики в газетах, періодичних виданнях, тематичних збірниках, монографічних виданнях.

Ключові слова: науковий доробок Миколи Зимомрі, літературознавство, теорія літератури, перекладознавство, рецепція, міжлітературні зв'язки.

Setting of the problem and relevancy substantiation. The principle seems natural: it is not easy to outline the strokes of a creative portrait. It's even harder when it comes to an attempt at generalization. After all, the anniversary event of each person contains a combination of different components that have the optimal basis for the interaction of a particular person with the environment, in fact, both literally and figuratively. Of course, it is a question of a certain correlation of the known, instead of imaginary effective facts, with a projection on a dialogue between like-minded people. Here the architecture of a meaningful approximation to the truth is based on reasoned dialogicity and its elements.

The purpose of the article is to reflect the main milestones of the life and career of Mykola Zymomrya.

Presentation of the main research material. For Mykola Zymomrya as a teacher, the educational field is the most important, because he gave it more than five decades of work in high school. It forms the basis of his creative aspirations, which should include other, no doubt, also effective competitions. He is now a well-known scholar-literary critic, an active bearer of literary translation, a member of the National Union of Writers of Ukraine, an Academician of the Academy of Sciences of the Higher School of Ukraine, an Honored Worker of Science and Technology of Ukraine. The essence of Mykola Zymomrya's competition is the desire to always understand the uniqueness of the dialogue of both individuals and the dialogue of cultures in general. Thus, since 1966 he has been sowing grain in the Temple of Knowledge, mastering the cultural values of different times and peoples. Besides, everything he wrote is probably remarkable, because he is imbued with a great love for his native land. And this love generates respect and love for other peoples, other cultures. Mykola Zymomrya found his destiny, vocation, revealed himself as a creative person in the field of literature. It is also about tradition and its movement, and for his part, if according to the theory of Wilhelm Humboldt, about the way of mastering the accents of the unity of language and thinking.

Mykola Zymomrya was born on November 30, 1946 in a peasant family. From time immemorial, the family lived in the village of Holiatyn in the Mizhhiria region, lost among the virgin forests of a large mountain range in Zakarpattia. By the way, the author of the three-volume history of Zakarpattia Ivan Dulyshkovych (1815-1883) was born here. His image has now returned to the father's threshold in the valuable artistic high relief stone by sculptor Mykhailo Belen. Holiatyn and the surrounding peaks were kindly mentioned by the Czech writer Ivan Olbracht in the famous novel about an opryshko (rebel) Mykola Shugai (1898-1921). Mykola Zymomrya finished a secondary school here, and then his life path led to the city above the river Uzh, where he studied at the departments of Ukrainian and German philology at Uzhhorod University. He graduated in 1967. M. Zymomrya was destined to taste teacher's bread at the fifth secondary school in Uzhhorod, where German was traditionally taught in the 1960s. Then for many years his destiny was connected with Uzhhorod University, where he worked as a German language teacher, head of the Department of German Philology (1973-1979), associate professor, professor, and head of the Department of Foreign Languages (1986-1993). Fate has boned Mykola Zymomrya to Ivan Franko Drohobych State Pedagogical University, where he founded the Department of Theory and Practice of Translation and had been its first head since 2001 . 
The department was reorganized into the Department of Germanic Languages and Translation Studies in the days of "optimization". It is still headed by a wellknown Germanist, by the way, the author of a thorough article on the German language in the columns of the Encyclopedia of Modern Ukraine.

Mykola Zymomrya's work biography was preceded by years of full-time studies at Humboldt University of Berlin (1969-1972). Within its walls, the native from the Silver Land successfully defended his dissertation "Perception of Ukrainian literature in German-speaking countries from its origins to 1917. To the history of Ukrainian-Russian-German literary relations" (Berlin, 1972). Its text is 639 pages long and is written in German. The researcher's study was highly praised by authoritative Ukrainian and German scholars, including the official opponent from Kyiv, Yaroslava Pohrebennyk (1931-2010), and the prominent Berlin Slavist scholar, Academician Eduard Winter (1896-1983).

M. Zymomrya's extensive dissertation gave a well-founded overview of the phenomenon characteristic of the works of I. Kotliarevskyi, H. Kvitka-Osnovianenko, T. Shevchenko, Marko Vovchok, I. Franko, Lesia Ukrainka, V. Stefanyk, O. Kobylianska, M. Kotsiubynskyi and other Ukrainian masters of the word in the context of the interaction that took place in different ways, including at the level of contact-genetic connections and artistic translation. The dissertation search of the Zakarpattia native received real recognition, in fact, as one of the prominent theorists of the paradigm of textual interpretation in Ukraine.

Ten years later were doctoral studies at the academic Institute of World Literature named after Maxim Gorky in Moscow (1980-1982), where Mykola Zymomrya represented Ukrainian science as a Germanist. Here he completed his doctoral dissertation "Interliterary Relations and the Role of Translation in the Art Process". It is important that this study was carried out in the framework of scientific cooperation between the Institute of World Literature and Humboldt University of Berlin. That is why the defense, which also took place in the same center where M. Zymomrya's postgraduate studies once took place, became natural. The two-volume book was the subject of a doctoral dissertation in late 1984. The scientific honesty of its author, innovative understanding of the interaction of literary systems as one of the important types of artistic communication in organic connection with translation - a "moving" factor in the artistic process in general - all this was emphasized by the official opponents, well-known scientists - Professors Yurii Borev, Mark Poliakov
(Moscow), Pavlo Kopaniev (Minsk), Manfred Jenichen and Anton Girsche (Berlin). Time has passed and that is why the emphasis is here: Mykola Zymomrya has managed to achieve a lot during many years of research. He has about two thousand publications. Although he made his literary debut in 1970, the first printed correspondence and essays appeared in 1959. They also started his journalistic preferences: in 1981 he was elected a member of the National Union of Journalists of Ukraine.

Mykola Zymomrya's research comprehends important phenomena of the literary process, comparative studies, and the interaction of the cultures of the peoples of Eastern, Central, and Western Europe. Among the outstanding components of his work are the following book editions: "Ukraine Poland: culture, lessons, and spiritual competitions" ("Україна - Польща: культура, уроки, духовні змагання", 1999), "Identity and partnership: studies of relations of the nearest neighbors" ("Тотожність та партнерство: студії взаємин найближчих сусідів", 2000), "Ukraine - Poland. Scientific Studies of Neighboring Partners" ("Україна Польща. Наукові студії сусідів-партнерів", 2004), "Ukraine-Poland.Monologue-Dialogue ofCultures" ("Україна - Польща. Монолог - діалог культур", 2004), "Ukraine - Poland: New Challenges of the Epoch" ("Україна - Польща: нові виклики епохи", 2006). They form a kind of series called "Ukraine - Poland" in five volumes (in six books). By the way, the collection "Beyond partitions. Common Perspectives and Achievements in PolishUkrainian Scientific Cooperation" ("Ponad podziałami. Wspólne perspektywy i dążenia w polsko-ukraińskiej współpracy naukowej”, 2021) edited by famous Polish scientists Leszek Pawelski and Marek Rembierz has just been published. It contains a detailed article about Mykola Zymomrya and his contribution to Polish studies in general and to UkrainianPolish cultural interactions in particular. The named bibliographic units are unambiguous evidence of labor progress. His scientific explorations are characterized by pronounced assessments, accurate emotional language, and fidelity to the developed stylistic manner. Among the priority facts that the researcher first introduced into scientific use, the ones that enrich the work of Taras Shevchenko, Ivan Franko, Lesia Ukrainka, Olha Kobylianska, Marko Vovchok, and a whole galaxy of German scientists and cultural figures deserve attention. With a great obsession and intense energy, the scholar is inspired by work, as he follows unknown and untrodden paths, explores unknown or little-known facts for the general reader, or questions that have long been silenced under 
the influence of various circumstances or eras.

Fate gave M. Zymomrya the opportunity to work in many archives and libraries of Lviv, Kyiv, Moscow, St. Petersburg, Riga, Tartu, Berlin, Leipzig, Weimar, Halle, Greiswald, Dresden, Cologne, Heidelberg, Warsaw, Krakow, Slupsk, Koszalin, Częstochowa ... The obvious persistence and happy temper allowed the philologist with the feeling of an "archaeologist" to find a number of unknown examples from the history of German-Ukrainian and UkrainianGerman, Ukrainian-Bulgarian, Ukrainian-Polish, Ukrainian-Hungarian cultural interactions, in short, to find and comprehend many new things about such prominent figures in the field of German culture as J. Ch. Engel, J. W. Goethe, F. Schiller, H. Heine, J. G. Herder, F. Bodenstedt, A. Leist, L. Jacobowski, G. Adam, K.-E. Franzoz, A. Sacher-Masoch, A. Sch. Wutzky, E. Winter and others. All of them to one degree or another - were involved in the history of Ukraine, its cultural heritage, served as mediators in the complex process of perception (and often borrowing) of the Ukrainian word in Western Europe and especially - In Austria and Germany.

The works of Mykola Zymomrya enriched, in particular, the German Shevchenko studies. Thus, in 1976, a large monographic study "On the perception of Taras Shevchenko's work in German-speaking countries" appeared in Berlin, and later several similar publications, which convincingly assessed the merits of many foreign researchers of Shevchenko's work. It is necessary to name such Slavists as H. L. Zunk, E. Keil, J. P. Jordan, J. Scherr, G. Karpeles, J. Virginia, V. Jagič, W. Kawerau, A. Jensen, G. Abel, M. Folticeano and others. Some of them were in fact unknown (Hermann-Leopold Zunk, Constantin Tischendorf) or little known (Johannes Scherr, Gustav Karpeles, Georg Adam, Anna-Charlotte Wutzky, Ludwig Jacobowski) in Shevchenko studies.

Among the many illustrations of reading Shevchenko's words, we can highlight the text of Kobzar's autobiography in German translation, which was published in Leipzig during the poet's lifetime in 1860. As a scholar, M. Zymomrya was the first in Ukraine to present this important fact and establish the name of the translator. Both this eloquent Germanlanguage interpretation and the case of the publication of Shevchenko's collection of poems in Leipzig in 1859 did not do without Panteleimon Kulish (1819-1897), a talented translator of Goethe's works, and a passionate popularizer of T. Shevchenko's works in Germany. These and other facts emerge from the pages of the monograph "Germany and Ukraine: in essays on the interaction of cultures" ("Deutschland und Ukraine: Durch die Abrisse zur Wechselseitigkeit von Kulturen"), which was published in German in the book series of the almanac of Ukrainians in Europe "Zerna" (Lviv, 1999). His Russian-language monographic work "Mastering Literary Experience. Continuity of the tradition of perception of Taras Shevchenko's work” (“Опанування літературного досвіду. Переємність традиції сприйняття творчості Тараса Шевченка”, Drohobych, 2003) deserves a special word. It is gratifying that it is the fruit of cooperation with his post-graduate student Olha Bilous. The book was published with the assistance of the Union of Ukrainians of Russia, in particular, with the active support of its chairman - Olexander Rudenko-Desniak (1936-2006). M. Zymomrya also has a Polish-language monograph - "Dimensions of spiritual competitions" ("Wymiary zmagań duchowych", Koszalin, 2006).

The register of Mykola Zymomrya's research harvest first of all impresses with the number of names, variety of creative directions and tendencies. His works create an "inner" integrity, imbued with the inalienable criteria of goodness, and a vision of eternal beauty. For example, only from M. Zymomrya's researches do we learn that $\mathrm{J}$. W. Goethe was one of the first to appreciate the merits of Ivan Orlai in science. In the funds of the Weimar Archives of Goethe and Schiller, the researcher found a manuscript of a letter written by Ivan Orlai in August 1806 to the creator of "Faust" - a valuable document of human relations between two contemporary figures. The researcher examines the scientific heritage of Zakarpattia natives through the prism of their ties with Russia, Bulgaria, Poland, Hungary, Austria, Germany, Slovakia and the Czech Republic (I. Orlai, M. Baludiansky, V. Kukolnyk, P. Lodii, and O. Dukhnovych).

The works of Mykola Zymomrya are characterized by a large source base, the originality of the author's conclusions and generalizations, and the conceptual depth of the scientist's observations. The works sound different, but they are united by the accuracy of the definition of tasks when it comes to thematic outline, for example, Germanlanguage Shevchenko studies, the artistic practice of many Ukrainian authors, whose works have become the subject of interest of German-speaking critics. All these are positive components of the process of national cultures interaction. For example, M. Zymomrya convincingly proved that the Germanlanguage works of Olha Kobylianska, Ivan Franko or Yurii Fedkovych do not imitate the creative palette of Goethe, Schiller, and Heine, but rather testify to the transformation of German classics into a new literary environment. 
A systematic analysis of the process of perception of Ukrainian literature in Austria and Germany, comprehensively conducted by the scientist, provides an opportunity to see the place of Ukrainian literature in the context of world culture. The researcher came to the right conclusion: the Ukrainian artistic word is still known to the world community, unfortunately, only at the level of representation of names, not works. In other words, the dynamics of cognition and recognition of the artistic thought of the vast majority of Ukrainian writers does not yet meet the need for reception, i.e. perception, which would determine the true face of Ukrainian national culture. Exceptions to this rule are T. Shevchenko, I. Franko, V. Stefanyk, M. Kotsiubynskyi, Lesia Ukrainka, V. Vynnychenko, and V. Stus. Such conclusions of M. Zymomrya are well motivated by the specifics of facts, typological parallels, and convincing observations. Therefore, it is appropriate to name the following fact. M. Zymomrya enriched the science of Shevchenko studies with new names (H. L. Zunk, E. Keil, L. Tischendorf), which were not previously considered in connection with the life and creative path of T. Shevchenko.

Mykola Zymomrya is interested in topical issues of cultural studies, local studies, ethnography, Ukrainian ethnopedagogy, art of national education, taking into account the self-identity of the bearer. This is clearly seen in such published articles as: "Views of German-speaking scholars on the ethnicity and language of the indigenous population of Zakarpattia" (1993), "Conceptual views of Avgustyn Voloshyn on the synthesis of education and upbringing in school and family" (1995), "Avgustyn Voloshyn as an outstanding scientisteducator of Ukraine" (1995), "On the genesis of good and evil in the educational assessments of Josyp Terelya" (1995), "Pedagogical thought and its place in the scientific heritage of cultural and educational figures of Zakarpattia" (1996), "Ecology and its universal principles in the literary process" (1997), "The jewelry of Ukrainian literature in the assessments of German scholars of the first half of the nineteenth century. To the 200th anniversary of the appearance of Ivan Kotliarevskyi's Aeneid" (1998), "Adam Mickiewicz in German-language reception and its reflection on Ukraine" (1999), "Typological interactions of literary phenomena in the process of reception" (2000), "Shevchenko and us. The Image of the Resurrection in Taras Shevchenko's Poetry" (2001), "The Moral and Ethical Value of Metropolitan Andrei Sheptytskyi's Messages" (2002), "Pedagogical Legacy of Olexandr Dukhnovych in Eduard Winter's Assessments"
(2003), "Alfred Jensen and his merits in the history of Polish-Swedish and Swedish-Ukrainian cultural ties" (2004), "Native language as a factor in the education of the individual in the context of Great Didactics by Comenius" (2005), "Translation as lifestyle. On the question of Ivan Franko's translation activity" (2006), "The Model World of Personality in the Dramas of Bernard Shaw, Ivan Franko, Volodymyr Vynnychenko" (2007), "P. J. Šafaryk's Creativity in the German-Speaking Reception and Its Publicity in Ukraine" (2008), "The Phenomenon of Hryhorii Kochur as a Translator: Discourse of Cultural Tradition" (2009), "Confessional power of "women's writing" as a phenomenon of Ukrainian culture" (2010), "Spirituality and rank: to the question of the importance of personality in the interaction of Western and Eastern Europe", "Creativity of Friedrich Bodenstedt: the context of GermanUkrainian-Hungarian literary interactions" (2011), "Creativity of Volodymyr Vynnychenko and Arthur Schnitzler: the essence of artistic pursuits" (2012), "Dimensions of identity in the art world of Taras Shevchenko through the prism of German reception" (2013), "The path to the emerald city. An Attempt at a Literary Portrait of Nataliia Naumenko" (2013), "Imperishable basis of human experience" (2014), "Works of Joseph Fishtyk in translated interpretations" (2015), numerous slogans in the Encyclopedia of Modern Ukraine $(2012-2021)$ and others. The scientist has published some works both in Ukraine and abroad, in particular, in Bulgaria, Poland, Russia, the USA, Slovakia, France, Germany, and Croatia.

Attention should be paid to the researcher's typological and contextual approaches to the study of the historical past of Zakarpattia in terms of the assessments of Hungarian, Czech, Slovak, German, Austrian, and Polish scholars. From this point of view, he examines in detail the scientific and artistic heritage of the natives of the Silver Land and its admirers from past eras and modern times (M. Baludianskyi, I. Orlai, V. Kukolnyk, M. Luchkai, O. Dukhnovych, P. Lodii, A. Voloshyn, V. GrendzhaDonskyi, Y. Borshosh-Kumiatskyi, S. Panko, L. Balla, P. Skunts, I. Chendei, V. Ladyzhets, S. Zhupanyn, V. Kokhan, O. Rischawy, P. Poida, V. Ihnat, T. Likhtei, Y. Shyp, O. Tymofiieva). The monograph "Avgustyn Voloshyn" was published in three editions $(1994,1995,2006)$, which found a positive assessment in the literature about the most prominent figure of Carpathian Ukraine (M. Mushynka, T. Bednarzhova).

Mykola Zymomrya has done a lot to return the lost treasures, revive the spiritual, moral and aesthetic values of the Ukrainian people, and hence the uni- 
versal values, humanistic achievements, which are usually "grounded" in spiritual competitions, such as Belarusian, Russian, Ukrainian, Polish, Slovak, German, Georgian, and Lithuanian peoples. For each of them, the researcher has a separate folder with materials compiled according to the scheme developed by him, which also belongs to the creative laboratory of the linguist. In this regard, special interest is given to numerous articles by $\mathrm{M}$. Zymomrya about the most active popularizers of Ukrainian literature in the countries of Eastern, Central and Western Europe, i.e. J. G. Herder, F. Bodenstedt, P. Todorov, E. Winter, E. Reisner, P. Kirchner, R. Göbner, R. Sembratowytsch, O. Horbach, M. Mushynka, I. Galaida, I. Udvari, Y. Tamash, I. Katschaniuk-Spiech, A.-H. Horbach. The point is that he has the ability to be proud not only of the national traditions of Ukraine, but also the national traditions of other peoples, to understand these traditions, to treat them with the same care as his own, to see their beauty, to delve into the feelings that the sons and daughters of these peoples feel about their history, culture, language. For example, the scientist managed to "decipher" an archetype, in other words, the key to understanding the epistolary of Marko Vovchok, the history of her works and, in particular, a unique collection of "Two Hundred Ukrainian Songs", which occupies an exceptional place in world folklore. The scholar shows considerable concern for the preservation of folk songs as an invaluable heritage of Ukrainian culture. Evidence of this is his collection of songs "Oh, there on the mountains, on top" ("Ой там горі, на вершечку", 1991; the second supplemented edition - "Verkhovyna Songs" ("Верховинські співанки", Drohobych, 2001), recorded in Mizhhiria coming from a folk singer, researcher's mother Hafia Zymomrya (1919-1995). The book contains a thorough essay by her son "The People's Well Is Inexhaustible" - an awe-inspiring story about the difficult fate of a highland mother... Later, the third collection of Hafia Zymomrya's lyrics was published - "The Boykos Songs" ("Бойківські наспіви“, Drohobych, 2008). It contains samples of kolomyiky in the records of Mykola Zymomrya, Hryhorii Demyan and Vasyl Kobal. This separate edition was edited by Oleksandra Nimylovych and a granddaughter of the folk singer - Candidate of Pedagogical Sciences Olena Yurosh (1971-2021), who wrote a significant monograph "Music education in Zakarpattia: the context of the educational process (1919-1939)" ("Музичне виховання в Закарпатті: контекст освітнього процесу (1919-1939)", Drohobych, 2007, 216 p.). Unfortunately, the talented daughter of Mykola Zymomrya passed away on March 10, 2021...
Mykola Zymomrya was one of the pioneers of the talent of the German-speaking poetess from Kushnytsia village in Irshava region, Olha Rischawy (1903 -1993), having published about twenty articles about her creative work. Two editions of her works in Ukrainian and German "Blue Journey" ("Голуба мандрівка“, Uzhhorod, 1979, 159 р.), "The price doubled for years" ("Рокам подвоєно ціну“, Uzhhorod, 1996, 240 p.), compiled by M. Zymomrya, gained good publicity. Both collections contain interpretations of P. Skunts (1942 - 2007), one of the prominent Ukrainian poets of our time. They are based on Ukrainian interlinear translations, which M. Zymomrya prepared for Petro Skunts as a translator. Among other editions compiled and published by M. Zymomrya, the following books should be mentioned: "Prayers of the Heart" by Yulii BorshoshKumiatskyi (Uzhhorod, 1995), "Raspberry Circle" (Lviv, 2000) by Mykola Slabak; two collections by Dmytro Pavlychko - "Thimble" (Koshalin, 2000) and "Kyiv in May" (Koszalin, 2001); "The Lemkos Thresholds" (Lviv, 2002) by Olha Petyk; "Yurii Hutsa-Venelin. To the 200th anniversary of his birth" (Uzhhorod, 2002); "Roots from Ukraine" (Lviv, 2000) and "Colorful Dreams" (Drohobych, 2003) by Pavlo Holovchuk; "Variety" (Koszalin, 2003) by Yakiv Hudemchuk, "Raw Emerald" by Nataliia Naumenko (Kyiv-Drohobych, 2013) and others. The textbook "Text. System. Poetics of the genre" (Drohobych, 2012), edited by H. Semeniuk, M. Zymomrya and M. Tkachuk is quite eye-cathing. It was preceded by similar works, including "Analytical Reading" (Uzhhorod, 1978), "Translation: Theory and Practice", Kirovohrad, 2001), "GermanUkrainian Conversational Practicum" (Drohobych, 2004), "German-Polish Conversational Practicum" (Drohobych-Częstochowa, 2006), "Phraseology: Significant Values" (Vinnytsia, 2008), "Radio Journalism: Text Discourse" (Drohobych, 2015; co-authors Yosyp Fishtyk, Mykola Tkachuk). Thus, the inquisitive student has the opportunity to join a diverse arsenal of sources. The variety of topics is notable for the research studies of the scientist. However, all of them inevitably touch on the issue, which is the core, when we call its subgroups: the interaction of national cultures, the theory and practice of translation, etc.

It is impractical to segregate the scientific interests of the creator. M. Zymomrya willingly researches the issues of literary criticism, linguistics, ethnography, folklore, history, pedagogy, bibliography, having time to say his word in different directions. This is also evidenced by his meaningful book positions: "Lifegiving competitiveness of education” (“Животворна 
змагальність освіти“, Uzhhorod, 2000), "Rainbow of enlightened memory" ("Веселка просвітленої пам'яті“, Drohobych, 2010), "Cathedral of Daily Grace" (“Собор щоденної благодаті“, Drohobych, 2012), "The essence of schooling in a non-national environment” (“Сутність шкільництва в інонаціональному середовищі“, Drohobych, 2012; "Yaroslav Hrytskovian's Pedagogical Legacy: The Context of Ukrainian Schooling in Poland") ("Педагогічний доробок Ярослава Грицковяна: контекст українського шкільництва у Польщі“", Drohobych, 2014; co-author Lesia Shagalla), "The context of tradition and innovation: the creative work of Mykola Tkachuk" ("Контекст традиції та новаторства: творчий доробок Миколи Ткачука“, Drohobych, 2015), "The road to the world of knowledge" (“Дорогою у світ пізнання“, 2016), "The system of cultural paradigm: the discourse of personality” (“Система культурологічної парадигми: дискурс особистості“, 2019), "Ivan Franko: a projection into the present" ("Іван Франко: проєкція у сучасність“, co-author Maria Yakubovska, 2020). On a side note, this monograph was nominated for the Ivan Franko International Prize (2021).

Those works by Mykola Zymomrya are also notable: "Sources of Eternal Beauty" (“Джерела вічної краси“, Uzhhorod, 1996), collections of documentary essays "Fate in People" ("Долі в людях", Drohobych, 2006), "Time and Life" ("Чac і життя", Drohobych, 2012), "The Prophetic Word of Taras Shevchenko" ("Віще слово Тараса Шевченка“, 2014), as well as a collection of an anthological type "Echoes. The Light of Taras Shevchenko's Poetic World" ("Відлуння. Світло поетичного світу Тараса Шевченка", Uzhhorod - Drohobych, 2014), which contains the best translated versions of Shevchenko's works in German. Recently, collections of original fiction by Mykola Zymomrya were published, including "Bell for Angels” (“Дзвін для ангелів“", Uzhhorod, 2014), "Rays of the Cold Sun" ("Промінці студеного сонця", Drohobych, 2015), "Samples of the Silver Land" ("Образки Срібної землі“", Uzhhorod, 2016), "Between the Carpathians and the Tatras. Blue Rainbow" ("Між Карпатами і Татрами. Синя веселка“, 2017), "Flight of a Life Dream" ("Політ життєвої мрії“, 2018), "Peaks of the Holiatyn Plowman" ("Верховини голятинського плугатаря“", 2020). These collections did not go unnoticed by both readers and critics. Extensive reviews of M. Zymomrya's fiction drafts were written by Oleksandr Astafyev, Lubomyr Senyk, Vasyl Marko, Nataliia Naumenko, Yosyp Fyshtyk and, in particular, Tadei Karabovych, who wrote numerous translations of Mykola Zymomrya's short prose in Polish. Thus, the collection "Thresholds in the hive. Collection of the stories by Mykola Zymomrya" ("Progi w ulu. Wybór opowiadań Mykoly Zymomryi”, Kalisz, 2019). It was edited by the famous Polish scientist and translator Jan Grzesiak, a professor of Adam Mickiewicz University of Poznan and the Higher School in Konin. He prepared a new edition, which contains a separate series of prose works by Mykola Zymomrya "Polish accents in my life" translated by Jan Grzesiak. Mykola Zymomrya's prose collections "Green Echo" (“Зелене відлуння", Uzhhorod, 2021) and "Beobachtungen aus dem Grünen" (Uzhhorod, 2021) have just appeared on the shelves in adequate German translations by Yana Hrytsai.

It is no exaggeration to say that $\mathrm{M}$. Zymomrya's work as a translator is important. There were wellknown collections with his interpretations of Dmytro Pavlychko's works in German ("Kyiv in May", 2001; "Princess of Europe" (2010) and Polishlanguage poetess Oleksandra Shevello in Ukrainian ("Harmony of the Psalm", 2003). A separate edition was published of the German-language translations of Anatolii Moisiienko's poems ("Poetry. Gedichte", Drohobych, 2013), including interpretations by Ivan Zymomrya and Mykola Zymomrya, who has a number of articles about Anatolii Moisiienko as a poet.

Mykola Zymomrya is a scientist and a teacher. These two elements merged in his person for life. They complement each other well, which defines the personality of a university professor in the modern interpretation as a high school teacher. He has given author's lectures and special courses in higher education institutions of Ukraine (Kyiv, Lviv, Odessa, Donetsk, Kirovohrad, Ternopil, Ivano-Frankivsk, Chernivtsi), Russia (Moscow, Orel, Ufa), Germany (Leipzig, Berlin, Munich, Saarbrücken), Hungary (Nyíregyháza, Budapest), Bulgaria (Blagoevgrad, Sofia); he taught German studies at Slupsk Pedagogical Academy, at Koszalin Humanities Higher School and at Polonia University in Czestochowa.

For more than thirty-five years, Mykola Zymomrya has been polishing his pedagogical steps within the walls of Uzhhorod National University. And for the next twenty years he has been working at Ivan Franko Drohobych University. Here and there the educator acquired pedagogical skills, the creativity that he considers systematically, in fact, as a purposeful, consciously organized activity, which is expressed in a set of conditions and factors of learning, education, and development of creative 
personality. All this with the appropriate purpose contributes to the optimal organization of the educational process, the reasonable variety of organizational forms, methods, tools, approaches, incentives for self-discovery of intellectual, cognitive, social opportunities of student youth, differentiation of boys and girls in the years professional training. Realizing the high vocation of the bearer of high principles of spirituality, Professor M. Zymomrya systematically and persistently deals with various issues of pedagogical science. Some of them are covered in articles about O. Dukhnovych, A. Voloshyn, as well as in essays about contemporaries - teachers of higher education, in particular, M. Yevtukh, O. Vyshnevsky, V. Skotny, Y. Kyshakevych, K. Siatetskyi, O. Poliarush, P. Rykhlo, V. Kravets, P. Hudyvok, L. Hrytsyk, T. Korolyova, T. Kosmed, H. Yastrubetska, H. Korbych, V. Ovsiichuk, L. Orshanskyi, P. Feshchenko, O. Cherednychenko and others. The scientist gives his talent and works in the name of a noble goal - mutual enrichment of cul- tures. Each of his achievements in this area goes to strengthen the humanistic feelings.

Conclusions. Finally, we note that Mykola Zymomrya is one of the founders and compilers of the almanac "Franko Field" in six volumes (“Франкова нива“, 2016 - 2020). Hе is a member of the National Union of Journalists of Ukraine (1982) and a member of the National Union of Writers of Ukraine (2008), Honored Worker of Science and Technology of Ukraine (2017). Winner of the B. Lepkhyi, I. Koshelivets, O. Hrytsai, S. Sabol (Zoreslav) and W. Mager (Germany) prizes, the Gold Medal of Polonia University in Czestochowa (Poland). In a word, with his creative achievements Mykola Zymomrya moves and expands the spiritual unity of nations. Without exaggeration, it is about his life field of inner preferences and spiritual aspirations. We sincerely wish Mykola Zymomrya good health, further fruitful work for the benefit of the native people and the Ukrainian state, which the scientist organically connects with the world with his research work. 